\title{
VIVAX MALARIA;
}

HEMATOLOGICAL CHANGES: A STUDY AT KARACHI.

1. FCPS pathology Department of Pathology PNS Hafeez Islamabad.

2. FCPS pathology Department of Microbiology $\mathrm{CMH}$ abbottabad.

Correspondence Address: Dr. Sikandar Hayat Khan Department of Pathology PNS Hafeez Islamabad, sik_cpsp@yahoo.com

Article received on: 15/12/2016

Accepted for publication: 20/04/2017

Received after proof reading: 05/06/2017

\begin{abstract}
Sikandar Hayat Khan', Muhammad Farooq ${ }^{2}$
ABSTRACT... Background: The primary health care physician is usually perplexed with regards to selection of initial therapy for patients presenting with fever. Some degrees of hematological changes do exist in most patients with malaria. How often these changes do exist with malaria in our set up? And whether these changes are due to associated fever or actually resulting because of malaria. Objective: 1-To measure the frequency of abnormal hematological changes in malaria patients in our set up. 2-To compare the hematological parameters among subjects with laboratory proven malaria, fever but no malaria diagnosis and healthy controls. Design: Cross-sectional analysis. Place and duration of study: This study was carried out from May 2010 to Dec- 2010 at department of medicine PNS SHIFA, and departments of pathology PNS SHIFA and RAHAT, Karachi. Subjects and methods: Subjects with history of fever and a clinical suspicion of malaria were recruited from primary physician's OPD along with healthy age and sex-matched control. First, the frequencies of various abnormal findings in hematological parameters were measured in subjects diagnosed to have malaria. Later, group-1: [Malaria (Laboratory positive) $(n=74)$ ], Group-2: [Fever (Laboratory negative) $(n=104)$ ] and group-3: [Age and sex matched controls $(n=54)$ ] were evaluated by one way ANOVA followed by post-hoc comparisons for significant differences among groups. Blood complete picture were measured by automated hematology analyzer (Specifications: CELTAC - alpha, MEK-6410 K). Malaria parasite presence was confirmed by both slide examination technique and immune-chromatographic (ICT) testing. Main outcome measures-Hemoglobin, white blood cells (WBC), platelets, PDW, \% neutrophil. Results- $21.62 \%$ cases from malaria had anemia, while the occurrence of leucopenia was $62.16 \%$. This leukpenia was associated with relative neutrophil excess $(63.51 \%)$. Thrombocytopenia was the most consistent finding among our studied subjects (97.30\%). The difference between the three groups were significant for platelets [Group-1, Malaria (Laboratory positive) group $=86.42$ (95\% Cl: 78.43-94.41)] [Group 2, Fever (Laboratory negative) group $=192.47$ (95\%Cl: 177.69-207.25)] and (Group-3, Age and sex matched control group $=278.89(95 \% \mathrm{Cl}: 254.16-303.62)]\{p<0.001\}$, and WBC [Group-1, Malaria (Laboratory positive) group $=5.55$ (95\%Cl: 5.08-6.01)] [Group 2, Fever (Laboratory negative) group $=6.68(95 \% \mathrm{Cl}: 6.14-7.20)]$ and (Group-3, Age and sex matched control group $=8.78(95 \% \mathrm{Cl}: 8.01-9.55)]\{\mathrm{p}<0.001\}$. The results for \% neutrophil and PDW were also significant, but post-hoc comparison did not show significant differences between groups thus differentiating a case of malaria from non-malaria fever or control. Conclusion: Malaria due to Plasmodium vivax is associated with thrombocytopenia and leucopenia in our set up. Moreover, the associated hematological parameters including \% neutrophil and PDW may help in augmenting a clinical diagnosis of malaria.
\end{abstract}

Key words: $\quad$ Malaria, hemoglobin, WBC, platelets, neutrophil, PDW.

Article Citation: Khan SH, Farooq M. Vivax malaria; hematological changes: a study at Karachi. Professional Med J 2017;24(6):859-864. DOI: 10.17957/TPMJ/17.3782

\section{INTRODUCTION}

Malaria has always enjoyed a great deal of victory over mankind since its evolution, and it is predicted that it will do so in future. ${ }^{1}$ There are regions which have demonstrated recent reductions in malaria cases, but Pakistan along with other countries of Eastern Mediterranean
Region are demonstrating an upsurge in malarial cases. ${ }^{2}$ While the numbers of malaria cases are increasing there is not enough being done by health care agencies, which lack both in the field of diagnostics and treatment. ${ }^{3}$ The diagnosis of malaria heavily relies upon the detection of malaria parasite by examining the stained blood 
slide for the presence of plasmodium species. This requires skilled laboratory staff along with dedicated time for ensuring detection of parasite in the blood in real time. ${ }^{4}$ The availability of rapid diagnostic kits with claimed higher diagnostic sensitivity is yet non-affordable to most labs across most developing countries. ${ }^{5}$ Moreover, the urgency of a malaria treatment plan on timely basis at the primary physician level will definitely improve malaria outcome in most places. ${ }^{6}$ So in this perspective the associated hematological changes may guide the physicians regarding the best management guidelines.

The search of literature reveals local and regional studies highlighting significant hematological changes among patients with malaria. ${ }^{7-9}$ However, certain controversies must be appreciated: Firstly, Are platelets always depressed in patients with malaria? The reported percentages of detecting thrombocytopenia vary from as low as $48 \%$ to as high as $93 \% .^{10,11,7}$ Moreover, the patients with fever and no laboratory proven malaria were also detected to have some degree of thrombocytopenia due to a different diagnosis or sometimes in response to initiated treatment. ${ }^{12}$ Secondly, The available search of literature reveals contrasting results about changes in other hematological parameters like hemoglobin and TLC. There have been studies documenting a less frequent depression of hemoglobin and TLC changes [13] to ones which showed a significant differences ${ }^{14}$ for malaria. Lastly, the newer generation of hematological analyzers also provides important details about parameters like red cell distribution width and platelet distribution width; what changes are there in subjects with a non-malaria fever and malaria? ${ }^{15}$

Keeping in view the increasing literature highlighted discrepancies and availability of several new hematology counter parameters, it was planned to measure the frequency of abnormal hematological findings in subjects with malaria. In the second phase an attempt was be made to compare the hematological findings among subjects with fever diagnosed to have malaria with fever subject with no malaria diagnosis and healthy controls.
MATERIALS AND METHODS

This study was carried out at departments of medicine PNS SHIFA, pathology PNS SHIFA and pathology PNS RAHAT, Karachi from May2010 to Dec-2010. The target population were subjects who were considered to have malaria at the primary physician level (Medical Reception Centre) and were advised slide examination for malaria parasite detection. Based upon the nonprobability convenience sampling, a total of 178 subjects were finally included in the study. Initial exclusions were subjects not considered to have malaria, and those having an alternative diagnosis like respiratory tract infection, enteric fever or others were excluded from the study. Later subjects diagnosed to have P.falciparum infection $(n=04)$, mixed infections $(n=07)$, and patients who had an earlier associated diagnosis $(n=04)$ were also excluded from the study. 54 age and sex matched apparently healthy controls without any symptoms were also included in the study. $4 \mathrm{ml}$ of blood was collected under aseptic conditions in potassium- EDTA phlebotomy bottle for analyzing:

\section{Blood complete picture}

Complete 18-part analysis of blood was carried out through automated hematology analyzer (Specifications: CELTAC - alpha, MEK-6410 K)

\section{Slide examination of blood for presence of malaria parasite}

The slides were stained as per the recommendations of Khan et al. [16] The initial examination was carried out by one experienced laboratory technologist, and later all slides were reviewed by pathologist.

\section{ICT malaria test}

Subjects who were considered negative by slide method were also tested by immunechromatographic test for malaria.

\section{Main outcome measures}

a) Hematological data recorded for further work-up included white blood cells (WBC), hemoglobin, platelets, haematocrit, red cell distribution width (RDW), neutrophil count, platelet distribution width (PDW). 
ß) MP slide positivity or negative status

\section{Grouping of Results}

Based upon the initial presentation of malaria at primary healthcare physician and the results of hematological investigations, following groups were formulated for study: Group-1, Malaria (Laboratory positive) group- $(n=74)$ : This group included subjects who had vivax malaria as detected on slide examination. Group 2, Fever (Laboratory negative) group-( $\mathrm{n}=104)$ : This group included subjects who had clinical suspicion of malaria but lab investigations ruled malaria out. Group 3, Age and sex matched controls- $(n=54)$ : Apparently healthy age and sex matched controls (without fever) were included in this group.

\section{STATISTICAL ANALYSIS}

All Data was analyzed by SPSS- version 15 . The gender and age differences among three groups were calculated by one way ANOVA (age) and frequency were measured by SPSS selection of descriptive statistics. In order to find frequency of low or high results from patients the $25^{\text {th }}$ and $75^{\text {th }}$ centile were defined using descriptive statistics in SPSS. The frequency of abnormal hematological changes in malaria patients were measured by using SPSS selection of descriptive statistics; while the results of various hematological parameters compared by one way ANOVA with Tukey's post-hoc comparison to know significant differences between groups. A value of $<0.05$ was considered as a significant.

\section{RESULTS}

The mean age among our data set was as: [Group-1, Malaria (Laboratory positive) group= $24.17+10.37$ ] [Group 2, Fever (Laboratory negative) group $=26.65+16.30]$ and (Group-3, Age and sex matched control group $=30.25+$ 18.71] [One way ANOVA: $p=0.088\}$ ].Gender wise, the female to male patients from our sample was 63/169.

The selected $25^{\text {th }}$ and $75^{\text {th }}$ centile cut-offs from our sample were as: Hemoglobin=11.2 $\mathrm{g} / \mathrm{dl}$, $\mathrm{WBC}=6.0 \times 10^{\wedge} 9 / \mathrm{L}$, Neutophil count $=70 \%$, and platelet count $=150 \times 10^{\wedge}$ 9/L. 16/74(21.62 $\%)$ cases from malaria group had anemia, while the occurrence of leucopenia was $62.16 \%(46 / 74)$ with relative neutrophil excess [47/74(63.51\%)]. The thrombocytopenia was a more consistent finding with occurrence of 72/74 (97.30\%). Table-I Out of the hematological parameters studied, only platelet count, WBC, \% neutrophil and PDW showed differences among subjects with and without malaria and healthy controls. Table-II However, Tukey's post-hoc comparisons suggested that the differences between groups were only significant for platelets and WBC, while neutrophil were only elevated (relative neutrophillic leukocytosis) in subjects with malaria without having much differences among subjects with fever without malaria and healthy controls. Similarly, PDW elevations were only raised in subjects with malaria. [Figure-1]

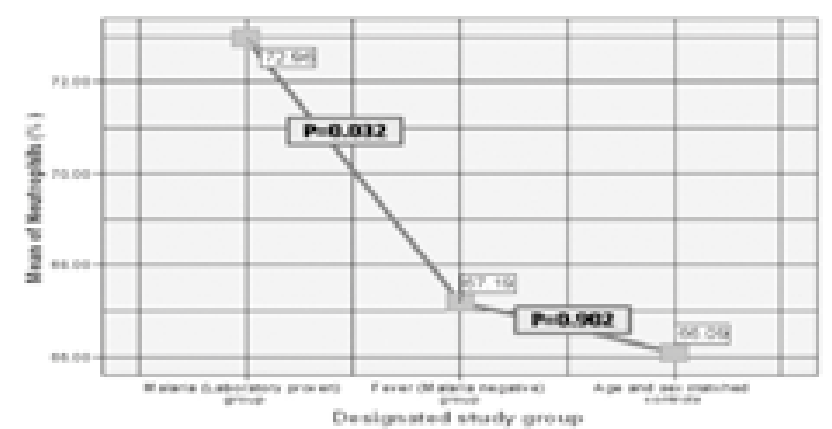

Figure-1. Differences in \% neutrophils among laboratory proven

malaria group $(n=74)$, fever without malaria group $(n=104)$ and age and sex matched controls $(n=54)$

[One way ANOVA $p=0.015$ ] with Tukey's post-hoc comparison not showing significance between fever without malaria group and controls.

\begin{tabular}{|c|c|c|c|c|c|}
\hline S. No. & Parameter & Selected cut-off & Cut-off & $\begin{array}{l}\text { No below/above the cut- } \\
\text { off /total malaria cases }\end{array}$ & $\begin{array}{c}\% \text { below/above } \\
\text { the cut-off }\end{array}$ \\
\hline 1. & Hemoglobin (g/dl) & $25^{\text {th }}$ centile & 11.2 & $16 / 74$ & 21.62 \\
\hline 2. & WBC $\left[\times 10^{\wedge} 9 /\right.$ MicroL $]$ & $25^{\text {th }}$ centile & 6.0 & $46 / 74$ & 62.16 \\
\hline 3. & Platelet count $\left(\times 10^{\wedge}{ }^{3} / \mathrm{L}\right)$ & $25^{\text {th }}$ centile & 150 & $72 / 74$ & 97.30 \\
\hline 4. & Neutrophil [\%] & $75^{\text {th }}$ centile & 70 & $47 / 74$ & 63.51 \\
\hline
\end{tabular}




\begin{tabular}{|c|c|c|c|c|c|c|}
\hline \multirow[b]{2}{*}{$\begin{array}{l}\text { S. } \\
\text { No }\end{array}$} & \multirow[b]{2}{*}{ Parameter } & \multirow[b]{2}{*}{ Group } & \multirow[b]{2}{*}{ Mean ( $\pm S D)$} & \multicolumn{2}{|c|}{$95 \% \mathrm{Cl}$} & \multirow{2}{*}{$\begin{array}{c}\text { Sig. } \\
\text { (On way ANOVA) }\end{array}$} \\
\hline & & & & $\begin{array}{l}\text { Lower } \\
\text { bound }\end{array}$ & $\begin{array}{l}\text { Upper } \\
\text { bound }\end{array}$ & \\
\hline \multirow{3}{*}{1} & \multirow{3}{*}{$\begin{array}{l}\text { Hemoglobin } \\
(\mathrm{g} / \mathrm{dl})\end{array}$} & Group-1 $(n=74)$ & $12.82( \pm 1.92)$ & 12.38 & 13.27 & \multirow{3}{*}{$p=0.925$} \\
\hline & & Group $2(n=104)$ & $12.72( \pm 2.16)$ & 12.30 & 13.14 & \\
\hline & & Group-3 $(n=54)$ & $12.70( \pm 1.81)$ & 12.20 & 13.19 & \\
\hline \multirow{3}{*}{2} & \multirow{3}{*}{$\begin{array}{l}\text { White blood cells } \\
\text { (WBC) } \\
{\left[\times 10^{\wedge} 9 / \text { MicroL }\right]}\end{array}$} & Group-1 $(n=74)$ & $5.55( \pm 1.99)$ & 5.08 & 6.01 & \multirow{3}{*}{$p<0.0001$} \\
\hline & & Group $2(n=104)$ & $6.68( \pm 2.74)$ & 6.14 & 7.20 & \\
\hline & & Group-3 $(n=54)$ & $8.78( \pm 2.83)$ & 8.01 & 9.55 & \\
\hline \multirow{3}{*}{3} & \multirow{3}{*}{$\begin{array}{l}\text { Platelet count } \\
\left(\times 10^{\wedge} 3 / L\right)\end{array}$} & Group-1 $(n=74)$ & $86( \pm 34)$ & 78 & 94 & \multirow{3}{*}{$p<0.0001$} \\
\hline & & Group $2(n=104)$ & $192( \pm 76)$ & 178 & 207 & \\
\hline & & Group-3 $(n=54)$ & $279( \pm 90)$ & 254 & 304 & \\
\hline \multirow{3}{*}{4} & \multirow{3}{*}{$\begin{array}{l}\text { Neutrophil } \\
\text { (\%) }\end{array}$} & Group-1 $(n=74)$ & $72( \pm 14)$ & 70 & 76 & \multirow{3}{*}{$p=0.015$} \\
\hline & & Group $2(n=104)$ & $67( \pm 16)$ & 64 & 70 & \\
\hline & & Group-3 $(n=54)$ & $66( \pm 13)$ & 62 & 70 & \\
\hline \multirow{3}{*}{5} & \multirow{3}{*}{$\begin{array}{l}\text { Red cell distribution } \\
\text { width (RDW) [\%] }\end{array}$} & Group-1 $(n=74)$ & $13.02( \pm 1.99)$ & 12.64 & 13.41 & \multirow{3}{*}{$p=0.087$} \\
\hline & & Group $2(n=104)$ & $13.45( \pm 2.74)$ & 13.17 & 13.72 & \\
\hline & & Group-3 $(n=54)$ & $13.71( \pm 2.83)$ & 13.24 & 14.19 & \\
\hline \multirow{3}{*}{6} & \multirow{3}{*}{ Hematocrit (\%) } & Group-1 $(n=74)$ & $40.4( \pm 6.3)$ & 38.9 & 41.8 & \multirow{3}{*}{$p=0.238$} \\
\hline & & Group $2(n=104)$ & $42.0( \pm 6.9)$ & 40.6 & 43.4 & \\
\hline & & Group-3 $(n=54)$ & $40.9( \pm 6.5)$ & 39.1 & 42.6 & \\
\hline \multirow{3}{*}{7} & \multirow{3}{*}{$\begin{array}{l}\text { Platelet distribution } \\
\text { width(PDW) [\%] }\end{array}$} & Group-1 $(n=74)$ & $14.53( \pm 1.42)$ & 14.06 & 15.00 & \multirow{3}{*}{$p=0.003$} \\
\hline & & Group $2(n=104)$ & $14.08( \pm 0.79)$ & 13.93 & 14.24 & \\
\hline & & Group-3 $(n=54)$ & $13.85( \pm 0.75)$ & 13.65 & 14.06 & \\
\hline
\end{tabular}

Table-II. Comparison of hematological parameters between subjects having malaria, fever with no malaria and age \& sex matched controls.

\section{DISCUSSION}

The frequency of thrombocytopenia in subjects with malaria was $97.30 \%$ in our studied population. Most studies have shown thrombocytopenia, but the occurrence varies from as low as $48 \%$ to as high as $89 \% .^{10,17}$ While patient's inherent metabolism and plasmodium species may influence degree of thrombocytopenia, most local, regional and other studies do support a higher degree of thrombocytopenia with plasmodium vivax. . $^{710,18,19}$ Leokopenia with relative predominance of neutrophils as an association to malaria was observed in our study. There is contrasting literature, albeit little exists in terms of findings from a retrospective study, where differences in WBC were not detected in majority of subjects with malaria. ${ }^{11}$ On the other hand, more evidence is available to augment our observations. . $^{8,10,19-21}$ Anemia as against to our observation, has also been increasingly detected to be associated with malaria in various studies. ${ }^{10,8,11,22}$ Clearly some of the above studies may suffer in terms of their strength due to their retrospective nature and small sample size ${ }^{10}$, but possible reasoning to this could be as following: Firstly, the available evidence shows that falciparum malaria has been more associated with anemia due to its possible additional effects of adherence to venular epithelium and enhancing apoptosis. .7,23,24 $^{2}$ Secondly, a study by Totino et al have documented that subjects infected by malaria parasite usually manifest anemia later in the course of disease. ${ }^{25}$ Our subjects in this perspective were sampled earlier in the course of disease at first presentation to primary healthcare physician, so a delayed sampling after 3-7 days could have shown some hemoglobin depression. Another study showing the rise and fall of hemoglobin with malaria suggests delayed appearance of anemia in contrast to platelet and leukocyte changes. ${ }^{26}$ Finally, there are some regional studies which like our results have not shown profound degree of anemia with vivax malaria. ${ }^{19,27}$ Keeping in view the anemia contrast demonstrated by our study and studies alike, a prospective multi-central trial covering different population groups and 
geographic terrains is recommended to address this highlighted controversy.

Another observation from our study was that \% neutrophils were able to differentiate between subjects having malaria and non-malaria groups including fever without malaria group and healthy controls, indicating that leucopenia in a malarial subject is specifically associated with relative neutrophil excess. Similarly PDW was observed to be raised only in subjects with malaria. These two findings are important as thrombocytopenia and leukpenia were to a certain degree associated with fever group without malaria. While this finding may require further elaboration through controlled trials, it may help differentiate malaria from other cases of bicytopenia in which leukpenia is associated with relative lymphocyte excess. ${ }^{28}$

Few limitations to our study must be acknowledged: Firstly the history taking and clinical examination may have been variable due to different physicians attending the emergency. However the study has not attempted to describe any of the clinical information for interpretation. Another limitation could be the variation linked to the day of sampling and the actual appearance of the disease manifestations. This could be one possible limitation to our findings. However, if we look into the study the objective was to help the primary healthcare physician at managing the fever patients.

The study has many clinical implications. Recently, the requests for malaria parasite detection through both the slide method and immunochromatographic methodsareincreasing. This practice is not cost-effective but also wastes a lot of technician's time for the detection of malaria parasite. A clinical and lab approach considering the initial data from the blood film examination will add higher yield at lower cost and better patient management. Moreover, the study underscores the utility of other hematological parameter like RDW and hemoglobin for detection of malaria.

\section{CONCLUSIONS}

Malaria due to Plasmodium vivax is associated with thrombocytopenia and leucopenia in our set up. Moreover, the associated hematological parameters including \% neutrophil and PDW may help in augmenting a clinical diagnosis of malaria.

\section{ACKNOWLEDGEMENT}

We would like to appreciate the technical assistance provided by our lab technologist Mr. Qamar Nadeem.

Copyright(C) 20 Apr, 2017.

\section{REFERENCES}

1. Guerra CA, Howes RE, Patil AP, Gething PW, Van Boeckel TP, Temperley WH, et al. The international limits and population at risk of Plasmodium vivax transmission in 2009. PLoS Negl Trop Dis. 2010 Aug 3; 4(8):e774.

2. WHO world malaria report-2009. Available at: http:// whqlibdoc.who.int/publications/2009/9789241563901_ eng.pdf.

3. Yasinzai IM. Kakarsulemankhel KJ. Frequency of various human malaria infections in hottest areas of central Balochistan, Pakistan: Duki, Harnai and Sibi. Pak Armed Forces Med J Sep 2008; 58 (3):276-85.

4. Kain KC, Harrington MA, Tennyson S, Keystone JS. Imported malaria: prospective analysis of problems in diagnosis and management. Clin Infect Dis, 1998; 27: $142-149$.

5. Anwar M, Hussain S, Qureshi A H, Ahmad M, Afzal S. Comparison of Optimal Malarial Test with Light Microscopy for the diagnosis of Malaria. J Pak Med Assoc Aug 2004; 54(8):404-7.

6. Ahmedl, Masroor M, Qamar R, ChannaSH, Imran K, Sattar A, Khan HM. Evaluation of Immunochoromatography (ICT) test versus microscopy for the diagnosis of Falciparum Malaria. Med Channel Jan - Mar 2007; 13(1):28-31.

7. Shaikh $Q H$, Ahmad SM, Abbasi A, Malik SA, Sahito AA, Munir SM. Thrombocytopenia in malaria. J Coll Physicians Surg Pak. 2009 Nov; 19(11):708-10.

8. Koltas IS, Demirhindi H, Hazar S, Ozcan K. Supportive presumptive diagnosis of Plasmodium vivax malaria. Thrombocytopenia and red cell distribution width. Saudi Med J. 2007 Apr; 28 (4):535-9.

9. Rodríguez-Morales AJ, Sánchez E, Vargas M, Piccolo C, Colina R, Arria M. Anemia and thrombocytopenia 
in children with Plasmodium vivax malaria. J Trop Pediatr. 2006 Feb; 52 (1):49-51.

10. Mert A, Ozaras R, Tabak F, Bilir M, Ozturk R, Aktuglu Y. Malaria in Turkey: a review of $\mathbf{3 3}$ cases. Eur $\mathrm{J}$ Epidemiol. 2003; 18(6):579-82.

11. Kortepeter M, Brown JD. A review of $\mathbf{7 9}$ patients with malaria seen at a military hospital in Hawaii from 1979 to 1995. Mil Med. 1998 Feb; 163(2):84-9.

12. Nazar HS, Rabbani A, Riaz A, Anwar J. Presentation of typhoid fever patients in Hazara Division and response to different treatment regimens. $J$ Ayub Med Coll Abbottabad. 2005 Jan-Mar; 17 (1):67-9.

13. Kumar A, Shashirekha Thrombocytopenia--an indicator of acute vivax malaria. Indian $\mathrm{J}$ Pathol Microbiol. 2006 Oct; 49 (4):505-8.

14. D'Acremont V, Landry P, Mueller I, Pécoud A, Genton B. Clinical and laboratory predictors of imported malaria in an outpatient setting: an aid to medical decision making in returning travelers with fever. $\mathrm{Am}$ J Trop Med Hyg 2002 May; 66(5):481-6.

15. Briggs C. Quality counts: new parameters in blood cell counting. Int J Lab Hematol. 2009 Jun; 31(3):27797.

16. Khan S A, Anwar M, Hussain S, Qureshi A H, Ahmad M, Afzal S. Comparison of Optimal Malarial Test with Light Microscopy for the diagnosis of Malaria. J Pak Med Assoc Aug 2004; 54(8):404-7.

17. Scott CS, Van Zyl D, Ho E, Ruivo L, Mendelow B, Coetzer TL. Thrombocytopenia in patients with malaria: automated analysis of optical platelet counts and platelet clumps with the Cell Dyn CD4000 analyzer. Clin Lab Haematol. 2002 Oct; 24 (5):295-302.

18. Kochar DK, Das A, Kochar A, Middha S, Acharya J, Tanwar GS, et al. Thrombocytopenia in Plasmodium falciparum, Plasmodium vivax and mixed infection malaria: a study from Bikaner (Northwestern India). Platelets. 2010; 21 (8):623-7.

19. Celikbaş AK, Ergönül O, Baykam N, Eren S, Güven $T$, Dokuzoğuz B. Malaria in Turkey and 14 years of clinical experience. Mikrobiyol Bul. $2006 \mathrm{Jul} ;$ 40(3):237-
43.

20. Tangpukdee N, Yew HS, Krudsood S, Punyapradit $\mathrm{N}$, Somwong W, Looareesuwan S, et al. Dynamic changes in white blood cell counts in uncomplicated Plasmodium falciparum and P. vivax malaria. Parasitol Int. 2008 Dec; 57(4):490-4.

21. Tangpukdee N, Yew HS, Krudsood S, Punyapradit N, Somwong W, Looareesuwan S, Kano S, Wilairatana $P$. Dynamic changes in white blood cell counts in uncomplicated Plasmodium falciparum and P. vivax malaria. Parasitol Int. 2008 Dec; 57 (4):490-4.

22. Kremsner GP, Greve B, Lell B, Luckner D, Schmid D. Malarial anaemia in African children associated with high oxygen-radical production. The Lancet 2000; 355(9197):40-41.

23. Magowan C, Wollish W, Anderson L, Leech J. Cytoadherence by Plasmodium falciparum-infected erythrocytes is correlated with the expression of a family of variable proteins on infected erythrocytes. J Exp Med. 1988 Oct 1; 168(4):1307-20.

24. Abdul Rasheed, Shahzad Saeed, Saleem Ahmed Khan. Clinical and laboratory findings in acute malaria caused by various plasmodium species. J Pak Med Assoc Apr 2009; 51 (4):220-3.

25. Totino PR, Magalhaes AD, Silva LA, Banic DM, DanielRibeiro CT, Ferreira-da-Cruz MD. Apoptosis of nonparasitized red blood cells in malaria: a putative mechanism involved in the pathogenesis of anaemia. Malar J. 2010 Dec; 9 (1):350.

26. González B, Rodulfo H, De Donato M, Berrizbeitia M, Gómez C, González L. Hematologic variations in patient with malaria caused by Plasmodium vivax before, during and after treatment]. Invest Clin. 2009 Jun; 50 (2):187-201.

27. Agravat AH, Dhruva GA. Hematological changes in patients of malaria. Journal of Cell and Tissue Research Vol. 10(3) 2325-2329 (2010).

28. Oliveira EC, Pontes ER, Cunha RV, Fróes IB, Nascimento $D$. Hematological abnormalities in patients with dengue. Rev Soc Bras Med Trop. 2009 Nov-Dec; 42(6):682-5.

\section{AUTHORSHIP AND CONTRIBUTION DECLARATION}

\begin{tabular}{|c|c|c|c|}
\hline Sr. \# & Author-s Full Name & Contribution to the paper & Author $=\mathrm{s}$ Signature \\
\hline 1 & $\begin{array}{l}\text { Dr. Sikandar Hayat Khan } \\
\text { Dr. Muhammad Farooq }\end{array}$ & $\begin{array}{l}\text { Data collection, Statistical } \\
\text { analysis, Analysis and write } \\
\text { up } \\
\text { Data collection, Analysis } \\
\text { and write up }\end{array}$ & \\
\hline
\end{tabular}

